\title{
Being in Public: The Threat and Promise of Stranger Contact \\ Davina Cooper*
}

Law \& Social Inquiry 32 (1) pp $203-232$

2007

\section{Not Published Version}

\begin{abstract}
: $\quad n / a$
Keywords: $n / a$
\end{abstract}

Laura Beth Nielsen. License to Harass: Law, Hierarchy and Offensive Public Speech.

Princeton, NJ: Princeton University Press, 2004 . \$47.50 cloth; \$22.95 paper.

There are few legitimate reasons for striking up talk with strangers (Gardner 1995, 64).

On the streets, the vernacular culture of the powerless provides a currency of economic exchange and a language of social revival (Zukin 1995, 46).

\section{INTRODUCTION}

License to Harass provides a sociolegal study of racially and sexually abusive speech within common outdoor spaces. Based on interviews with street users across three Californian cities, Laura Beth Nielsen's book examines subjects' "experiences with offensive public speech, their attitudes about the extent to which it poses a problem for American society, and their beliefs about whether the law should be employed to restrict" it (Nielsen 2004, 2). At the heart of Nielsen's account is an interrogation of how members of the public see law's role-should law be used to regulate or ban socially insulting speech, and, if not, why not? What place, in particular, do "free speech" principles occupy in the case against state regulation?

*Davina Cooper (d.s.cooper@kent.ac.uk) is Professor of Law and Political Theory at the University of Kent, and Director of the AHRC Research Centre for Law, Gender \& Sexuality. She is the author of Sexing the City (1994), Power in the Struggle (1995), Governing Out of Order (1998), and Challenging Diversity (2004). I want to thank Jon Goldberg-Hiller, Emily Grabham, Didi Herman, Martha-Marie Kleinhans, Laura Beth Nielsen, and the two anonymous $L S /$ referees for their helpful feedback and comments on earlier drafts, my thanks also to Suhraiya Jivraj for her excellent research assistance. The second half of this essay draws on research funded by the Leverhulme Foundation and the AHRC Research Centre for Law, Gender and Sexuality. 
Nielsen approaches harmful speech from a sociological perspective attuned to differences in social status: how "white women and people of color are much more likely to personally experience offensive public speech than are white men" (2). Yet the fact that subordinated constituencies experience speech-based harm does not mean they advocate legal solutions. According to Nielsen, her data suggests a broad consensus against legal intervention. Reasons for rejecting law vary, however, according to the effects race and gender positioning have on people's attitudes and experiences (128). So, while privileged white men reject regulation on grounds of freedom of speech, other constituencies oppose intervention by law and its officials on grounds of impracticality, institutional distrust, and a preference for individuals to deal with offensive speech themselves.

In this review essay, I read License to Harass as a way into the problematic of stranger contact in public. License to Harass works from the premise that public spaces are governed by norms of "civil inattention" (Goffman 1963, 84); as a result it tends to read public stranger contact negatively, focusing on the ways harassment contributes to the reproduction of social inequalities of race and gender in particular. Without disputing the reality of harassment or its injury, I wish to respond in this essay to the problematic of making "the study of racist street speech, sexist street speech, and begging ... the basis for a sociological inquiry into the nature of being in public" (4).1

My approach to doing so is twofold. I start with Laura Beth Nielsen's book, focusing on four themes that strike me as pivotal to understanding its claims and premises. They are publicity/privacy, strangers, (mis)recognition, and effects. I then go on to supplement my account of License to Harass with perspectives from geography, sociology, and cultural studies that offer a more positive picture of stranger interactions, where norms of civil inattention are reversed (rather than simply being transgressed). In so doing, I also draw loosely on legal pluralism as a way of thinking about the diverse character and interrelationship of social and regulatory norms, as they operate within, but also between, spatialized practices (Kleinhans and Macdonald 1997; Tamanaha 1993, 2000; Teubner 1992). To concretize my discussion, in the second half of this essay, I introduce two small-scale counterexamplesLondon's Speakers' Corner and the Toronto Women's Bathhouse. At first glance, these spaces seem far removed from the terrain of License to Harass, not least because they are located some geographical distance from the Californian sites of Nielsen's study. However, these local spaces of social invention provide what I think is a useful counterpoint to street harassment. Underpinned by different motivations and norms, they demonstrate how strangers, and what many would deem rather "strange" behavior, can rework the connections between public and private, between recognition and misrecognition, and between contact and inequality.

1. Emphasis added. 


\section{LICENSE TO HARASS}

\section{A. The Stranger}

The stranger is a subject who has been understood in the West in very different ways over the past eighty years. Sara Ahmed (2000) makes the important point that strangers are not real subjects but socially constituted, discursively produced positions. In this essay, my starting point is with the stranger as understood by Nielsen and her subjects - that is as someone who has not been knowingly encountered before. Social, cultural, ethnic, or economic forms of distance or alienation frequently underpin this personal unfamiliarity. Unintelligibility may also do so. This does not mean the stranger is unreadable. What it does suggest, however, is that from the perspective of the standpoint holder, they appear too normatively different or dissonant to be explained to others (even as they may be affectively experienced and even engaged with by the standpoint holder themselves).

In addressing the stranger, my analysis draws on three clusters of writing. The first focuses on the stranger as outsider. Initially grounded in the particular, early twentieth-century experience of the Jewish diaspora, the concept of the stranger signified the paradox of the one who was present, yet did not belong (Simmel 1971; see also Bauman 1988-89, 1995; Park 1928). In her book, The Modern Stranger, Harman (1988) explores how the concept of the stranger changed through the twentieth century as urban life and demographics shifted. In the current era of residential mobility and social diversity, the stranger may be better seen as a cosmopolitan, expert navigator-moving between and making sense of the different communities in which she or he temporarily resides (see Chambers 1990). Others, conversely, have described the stranger as a position of interpretive failure or dispossession-the one who cannot, or who can no longer, understand the signs and symbols through which public communication takes place (Harman 1988; Jackson 1998, 187). Yet, skilled or deskilled, to read the stranger as distinctively positioned on the social margins may no longer seem appropriate in the context of socially heterogeneous societies-where all seem equally to be outsiders or to belong. In such contexts, the stranger may be less a location of asymmetrical otherness than a relationship between complexly understood and configured "unknowns" (see also Wells 1995). The second literature on which I draw focuses on the way social relations, such as gender and ethnicity, and structures, such as capital, inform how people understand, interact, and coexist with other unknowns (Berman 1983; Zukin 1995). Much of this work has focused on the changing character of public space, as traditional public venues (Boddy 1992) have been replaced with new commodified places, such as shopping malls (Crawford 1992), tourist spaces (Gotham 2002), and festival marketplaces (Goss 1996). Yet, these shifts have not gone uncontested. 
Alongside accounts of the enriching social interaction between differently positioned strangers, other scholarship has explored the contests and conflicts routinely engaged in as people divided by class, age, gender, and ethnicity struggle to shape and define particular places (e.g., Coleman 1997; Mitchell 1995; Staeheli and Thompson 1997).

The third cluster of work moves away from analyzing relations of difference to focus on the (fleeting) encounter between those personally unknown to each other (e.g., Goffman 1963; Lofland 1973). Within these microencounters, etiquette and convention are central, yet vulnerable to failure. License to Harass is located at this juncture of seemingly failed norms. Against the celebration of public space offered by many cultural geographers, Nielsen's focus on street harassment echoes descriptions of urban life as structured by anomie, social isolation, and distrust (e.g., Wirth 1938; also Franck 1980), where dangers emerge from people's lack of a shared commitment to a space not properly and fully theirs (e.g., Newman 1973; Wilson and Kelling 1982). In a context in which contact threatens injury, "civil inattention" (Goffman 1963, 84) represents a foundational convention, aspiration and norm. Civil inattention gives "to another enough visual notice to demonstrate that one appreciates that the other is present ... while at the next moment withdrawing one's attention ... so as to express that he [sic] does not constitute a target of special curiosity or design" (Goffman 1963, 84).

[T]he individual must be "good" and not cause a scene or a disturbance; he must not attract undue attention to himself, either by thrusting himself on the assembled company or by attempting to withdraw too much from their presence. He must keep within the spirit or ethos of the situation; he must not be de trop or out of place.

Lofland $(1973,146-47)$ addresses the mechanisms people use to create symbolic shields, transforming public spaces, such as bus terminals or airports, into quasi-private ones. The trick, she argues, is to sustain being inconspicuous, to make it clear one is unavailable for social interaction. The techniques described by Lofland to maintain civil inattention resonate with informants' comments in License to Harass, as Nielsen explores how members of the public within three Northern Californian cities negotiate street harassment. Nielsen's interest here is threefold: what people do to avoid street harassment (and what, if anything, they do when they confront it); their views on whether external regulatory structures, such as law, should be deployed to counter insulting and degrading comments by strangers in public spaces; and their views on the relative harm of different kinds of street harassment.

\section{B. Encountering Harassing Stranger Speech}

Begging provides an entry point for Nielsen's discussion of the social politics of legal intervention. She writes, "The courts have been more tolerant 
of legal restrictions on begging than on other forms of public speech" (Nielsen 2004 , 3). Nielsen locates this more tolerant response in two things. First, Those targeted by begging are members of dominant social groups: "the law protects people from harassment and annoyance when they are of a certain social status" (26). Secondly, begging produces judicially recognizable harm, as opposed to merely offensive speech (18). License to Harass explores the norms and social conditions underpinning constitutional determinations about which speech should be protected and which open to prohibition. It argues that different speech receives different treatment and that this is conditioned by social power. At the same time, this is far from being a crudely instrumentalist account-Nielsen signals the complexity of First Amendment doctrine in relation to harassment and intimidation (20-28). However, to the extent constitutional free speech rights prohibit authorities from banning publicly performed racial and sexual utterances, Nielsen asserts that "the burden of free speech is dramatic and largely is borne by white women and people of color" (12).

Informants in License to Harass bolster these claims. Unlike begging, where it is those begging who are seen as the primary victim or vulnerable figure, Nielsen's informants identify "offensive public speech ... [as] a personal and social problem" for those on the receiving end of harassing utterances (93). Interviewees were, however, divided on the question of whether law was the answer. Some supported regulation for reasons that included the severity of the harm, the entitlement to be undisturbed in public spaces, and the positive symbolic effect of restrictive laws on wider perceptions of gender and race (102). However, for many interviewees, including, importantly, those who frequently found themselves harassment's target, legal intervention was not identified as a good solution (86-93). This was not because interviewees failed to see harassing speech as problematic, but because many doubted the utility and rightness of law as a weapon for tackling this kind of wrong.

Nielsen breaks down, by race and gender (among other things), the reasons interviewees gave for not supporting legal intervention. Many women, for instance, told Nielsen they did not want the power of prohibition and penalty to be in the state's hands. Yet, Nielsen argues her interviewees gave little evidence that women routinely contested harassing speech themselves. "The reinscription of hierarchies of race and gender goes on in public places largely unchallenged by targets" (134). Even if we bracket the question of whether more speech can undo men's public sexualization of women (see MacKinnon 1996; also Cohen 1999), the exit strategies Nielsen encountered, such as walking away, problematize the First Amendment voice-proposition that "counter-speech is the accepted means by which people . . . respond to speech they dislike" (117).

Nielsen's data also provides little indication of any routine restaging or resignifying of speech-queering strategies commonly associated with Judith 
Butler (1997; also Cover 2002; Schwartzman 2002). Interviewees talked, instead, about the "detailed calculus" they performed to avoid situations of risk (Nielsen 2004, 57-65), and their accompanying mental tactics of selfprotection (see also Gardner 1995; Lenton et al. 1999). Nielsen writes, "Blaming the speaker ... and the other psychological coping strategies engaged in ... are important because they are the way that targets continue to be able to travel in public spaces by resisting the hierarchical worldview represented by the comments of the speaker" (Nielsen 2004, 156-57). At the same time, while simply ignoring remarks proved common, Nielsen draws attention to how recipients also disavowed the relationship between degrading speech and its effects through "laughing it off," "externalizing" the problem to "this man," and through "denial" (156). In other words, many recipients of harassment chose to deliberately misrecognize the words or their intent in order to resist or diminish utterances' stigmatizing capacity.

License to Harass highlights the complex, socially differentiated character of how people experience and calculate their safety in relation to public spaces.2 In so doing, it lends support to work challenging republican liberal claims that people encounter each other and share public spaces as socially unmarked, homogenous citizenry. At the same time, for me, in reading the book, some other different questions arose. What is it about the stranger that makes her or his speech harassment, and what does being a stranger mean in this context? How significant are publicity and recognition to the damaging character of strangers' speech? And what personal and social work is performed by degrading stranger remarks?

\section{Understanding the Stranger}

License to Harass considers speech that appears offensive on its face; it also deals with utterances whose harm derives from the relationship at stake. In cases of "sexually suggestive remarks from strangers in public places ... many women report that any speech from a stranger in a public place, no matter how well intended, is perceived as offensive and/or threatening" (44).3 This latter is speech that pierces one's affective skin-that counters the normative assumption that strangers relate to each other in specifically authorized, largely silent, "front-room" ways. But who are the strangers of Nielsen's book? On the surface, Nielsen's concern appears to be with personal unknowns, fellow street-users never before encountered. Nielsen describes how her interviewees felt less threatened when street-users, such as panhandlers, became known or recognized (42). "Frequent contact with a particular

2. For quite a different account of women's fear and boldness in response to street harassment anxieties in the Finnish context, see Koskela (1997).

3. Emphasis added. 
panhandler reduces the level of threat because the panhandler becomes a known commodity" (42).4 At the same time, articulated to this theme of the "unencountered" is a view of strangers as socially different. This perspective is not developed directly. However, it surfaces repeatedly in interviewees' remarks that harassing strangers differed from them on grounds of ethnicity, gender, and, to a lesser degree, sexuality. This is perhaps unsurprising; it is unlikely perpetrators of sexual or racial harassment would target those perceived as sharing their gender or ethnicity; heterosexual men, for instance, do not usually sexually harass other heterosexually presenting men. At a conceptual level, however, Nielsen's discussion raises two questions. Is social difference merely a contingent quality of the stranger-present perhaps in cases of harassment but not fundamental to the very concept (or conception) of the stranger; second, how does the contingency of social difference intersect other dimensions of strangerness, such as normative outsiderness or unintelligibility?

How the stranger is conceptualized is not an arcane point. It goes to the heart of the problematic articulated-namely, harassing speech from strangers. It also goes to the heart of the responses harassment generates. How to challenge or eliminate offensive speech depends on knowing what kind of stranger one is dealing with-beyond their status as a person not previously encountered. Legal pluralism may be helpful here. While Nielsen's legal consciousness is useful in exploring the different ways people think about and engage with law, legal pluralism is helpful to understanding contact across divergent normative orders. Thus, while the harassers in the book are largely presented as challenging, rather than articulating, alternative conceptions of good conduct (see also Day 2001), an alternative approach is indicated in Macdonald's $(1998,79)$ claim that "non-conforming behaviour in any particular regime is not simply a failure of enforcement or civil disobedience. It may be the reflexion of an alternative conception of legal normativity."

What Nielsen's account suggests is both a polysemic understanding of the stranger and the way different understandings, driven also by different contexts and interactions, shape individual informants' responses. At one end of the spectrum, the stranger is read as normatively other-as Nielsen describes in relation to "hidden responses-reinterpreting the event as external to the target" (Nielsen 2004, 145). The recipients of harassment may not explicitly vocalize their opposition, but what is clear from their described internal processes is "the targets' rejection of the worldview invoked by the speaker" (145). At the other end of the spectrum, the stranger relationship is read more thinly; here, despite the difference of social position, targets

\section{Nielsen's data is interesting in the light of other research that suggests hate crimes} and harassment are often committed within a range of relationships that cannot be reduced to or easily described as one of strangers. For a review of the literature and discussion of the U.K. context, see Mason (2005). 
of harassment may be less confident that colliding normative orders are at stake. Instead they may see the problem as lying in their failure to understand what the speaker intended or, conversely, in the harasser's rejection of ostensibly shared norms. Thus, the harassed wonders whether she has mistaken a compliment for an insult (as some interviewees described in the case of men's sexualized remarks to women), believes the harasser just needs to be taught why, for instance, racism is wrong (123), or strives to establish common ground, embarrassing the speaker as a means of (re)incorporating him into what she sees as their shared normative and epistemological framework.

\section{Inappropriate Private}

How we think about the stranger, and why we care about the personal remarks they make, fundamentally relates to the challenge those beyond our emotional skin pose when they pursue an involuntary form of entry. Harassment breaches a foundational tenet of privacy as "garment," that people in public places have the "right not to be spoken to by strangers" (Sennett 1994, 343). In describing how women experience "even 'polite' remarks," Nielsen writes, "these sorts of incidents serve as reminders that 'polite' Remarks from strangers in public places can be followed by less polite and sometimes even criminal behavior" (Nielsen 2004, 47). 5 Nielsen's analysis does not dispute civil inattention's authority as a governing norm (32); rather, she argues the primary flaw of Goffman's account is his failure to locate civil inattention within a broader theorization of how social power and domination are reproduced in public interaction.

At the same time, License to Harass complicates a simple, spatialized public/private divide. Although Nielsen reads harassment as personal or private speech from strangers in public (50), she also highlights how harm emerges from, and is accentuated by, the privatised character of the contact (compare Cowan and Hodge 1996). While some scholars have focused on the particular injury that is generated by hate speech uttered in others' presence, Nielsen questions the idea of "presence," when she suggests that white people do not tend to "hear" racism or men "sexism" (55). While utterances occur on streets or on public transport, their circulation is kind of private (66). "Offensive speech often is accomplished in very private ways despite the broader public contexts in which these interactions occur" (120). This private quality is not due to gatekeepers, entry conditions, or ownership structures. It emerges out of a combination of speaker tactics, and bystanders' refusal or antipathy to bear witness when violence, embarrassment, or social awkwardness threatens to arise (Goffman 1972).

5. Emphasis added. 
Privacy also functions as a feature of the harassing utterance itself, or, to put it more precisely, from the relationship or contact forged out of the privatizing work the utterance performs. In the apparent absence of Jacobs's (1961) "eyes upon the street," recipients can feel coerced into replying, trapped by conversational norms that assume one remark necessitates another (Nielsen 2004, 151). This process is not straightforward. Competing norms of good female conduct suggest unwanted, sexualized remarks must be ignored - that to respond is to become implicated in a voluntary exchange. However, even where recipients do ignore utterances, some of the harm or discomfort arises, I think, from what is experienced as the unreciprocated imposition by the harasser of private sphere conventions that presume voluntary, symmetrical contact.

\section{Misrecognition}

One issue raised by this crossing of expectations is that of misrecognition. Nielsen returns to misrecognition several times, addressing the apparently ambiguous borderline between acceptable heterosexual interest and sexual harassment (e.g., Nielsen 2004, 4, 44, 96). "Both men and women want to allow men to 'pick up' women. Sexually suggestive speech between strangers in public places may be one way that this occurs" (96). However, three other kinds of misrecognition are also relevant. They are misrecognizing where one is and the norms that prevail as a result; misrecognizing the intentions and agenda of the other through coming to the situation with divergent interpretive frameworks (see also Anderson 1990); and misrecognizing whom the other is.

I have already referred to the first two, so let me say something briefly about the third. For the most part, License to Harass reads gender, sexual orientation, and race as indicating real, distinct categories of difference. For instance, Nielsen writes, "race-related . . . comments between strangers ... . are but one way that division between races is reinforced and maintained" (Nielsen 2004, 82). 6 Although this can be read as suggesting the social constitutedness and even the contingency of race, it can also be read as indicating that while the distance between "races" is open to change, the very presence of racial difference- - that there are "people of all races" (49)—is not. License to Harass tells a story of street exchanges between people who are men or women, white or of color-identifications seen, for the most part, as stable and present, independent of the context in which they are hailed.7 As a result, the book tells a story in which the process of being hailed is, for the

6. Emphasis added.

7. Similarly clear categories are apparent in the questionnaire Nielsen uses (see appendix

B), where the informant is assumed to be male or female (qu. 35), and to have "a race" (qu. 36). 
most part, a straightforward one, with harasser and target holding a shared and agreed knowledge of the target (and harasser's) social location.

License to Harass does narrate instances where targets of harassment feel they have been misrecognized. In one instance, a man self-identified as heterosexual complains about receiving sexually explicit compliments from other men (73); in another case, a woman describes strangers' confusion at witnessing a white mother with a black child (50). Yet, claims of misrecognition support rather than challenge the possibility of collectively knowing who people are. In other words, the very idea of misrecognition holds out the promise of equivalence or transparency between the frameworks of intelligibility of those involved. This does not necessarily require an objectivist approach to identity (that people have a true gender and racial identity which can be discovered). However, it does suggest we should all be able to agree on what someone's gender, race, or sexual orientation is (thanks to authoritative and shared social criteria for determining it), even if people get it wrong at times. Teubner's (1992) claim that law productively misreads other discourses for, and in the course of, its own norm generation is helpful here. It allows us to think about the harasser's accusation of the other as "gay," for instance, less as a form of misrecognition than as a "productive" if hostile rereadingboth of the term gay and of who the one targeted by the harasser is.

Where does this get us? I do not want to deny the significance of people's self-identity claims nor the power of hegemonic schema through which individual and collective social positions are materially produced. However, the possibility of challenging organizing principles of inequality depends also on being able to convert social distinctions, such as gender, into characteristics that have far less or quite different discursive and material signifiance (Cooper 2004). It is in pursuit of this that asserting the incommensurability or essential contestability of labels and categories may play a part.

\section{Relating Harassment to Power}

My final concern goes to the question of speech's effects. As Nielsen states, one key dimension of First Amendment debate is the role intelligent and political speech is presumed to play in promoting self-governance and democratic deliberation (Nielsen 2004, 28-29). While "free speech" is legitimated on other grounds, its public sphere function is central. Yet in questioning the extent to which public speech necessarily promotes public debate, 8 Nielsen goes further to focus on the harm stranger speech can cause, particularly in

8. License to Harass resonates with some scholarship on public space, which questions the idea that strangers primarily interact with each other as citizens engaged in rational, deliberative speech (see also Calhoun 1992; Jankowiak and White 1999, 339). For an account of the relationship between public sphere and public space, see Goheen (1998). 
its reproduction of social inequality. Nielsen writes, "street harassment is simple: the person with privilege asserts it over the person that is less privileged" (35). At the same time, Nielsen recognizes that the relationship between harassment and power is not straightforward; those with less socioeconomic status, usually men, may also use gender and racial harassment to trouble or disrupt their subordinate class position (35). 9 But how important is street harassment to reproducing or, conversely, to contesting relations of inequality, and how does harassment intersect other technologies of social power?

License to Harass concludes with the claim that material harms of unequal pay, domestic violence, and workplace discrimination outweigh the "dignitary harm associated with an offensive comment" (178); yet, the book's ambition is to examine and explain the power of direct, unmediated speech. For Nielsen, street harassment has a distinctive place within relations and practices of inequality because it "is naked in its reference... It remains one manifestation of inequality that cannot be excused or ignored as symptomatic of something else" (178). Sexist and racist utterances may be officially and socially frowned upon, but they are normative-reinforcing established asymmetries of social power and belonging-including the asymmetrical coding that renders certain social dimensions, such as maleness and whiteness, unmarked and unremarked upon (see also Hill 1998).10 In characterizing subordination as a system, Nielsen emphasizes the extent to which different kinds of gender and racial practices reinforce each other (see also Day 2001; Gardner 1995; Lenton et al. 1999). But what is the relationship between these systems of power; how contradictory are they in their own internal operations; and how open are they to intervention and disruption?

\section{CEDING PUBLIC TERRAIN}

When women choose to be in public, being the target of [invasive public] speech, or simply fearing being made the target of such speech, is the price they pay (Nielsen 2004, 49).

I want now to broaden my discussion of public stranger contact, and to pick up some of the questions raised. But before doing so, let me conclude this initial discussion with four claims about the book. License to Harass makes an important contribution to debates about law and offensive speech through

9. Harassment functions as a means of demanding attention and making contact on terms that contravene conventions for exchange established by the socioeconomically powerful (even as the form and content of the harassment underscores and exacerbates the social distance between harasser and target) (see also Jankowiak and White 1999, 341).

10. Although if comments go "too far," and are seen as out of line with a newly evolving status quo, they may undermine the emerging dominant social order, as Calavita (2001) explores. 
its careful research and analysis of how people experience public utterances, and their views on legal remedies, drawing on the work of Ewick and Silbey (1998) on legal consciousness (see also Merry 1986, 1993; Silbey 2005). This is a book that brooks no easy answers. Nielsen powerfully portrays the problem of street harassment and the contribution it makes to ongoing gender and race-based subordination; she reveals how the law is not innocent, that by protecting offensive speech, it normalizes subordination, and "offers a license to harass" (Nielsen 2004, 170). At the same time, Nielsen demonstrates that being on the receiving end of harassment and intimidation does not lead people to necessarily advocate legal solutions. License to Harass explores reasons why different sectors of society reject or feel uncomfortable with the idea of more law, even as the strategies and tactics individuals adopt instead seem limited in their reach.

Yet, while there is much of value in the book, I want to outline three directions in which I would have liked to see discussion go further. This is not to criticize License to Harass. One of the book's strengths is its tight focus; and inevitably, this means bracketing issues identified as peripheral or less central. However, Nielsen's account of being in public would, I think, have been productively complicated by engaging more directly and reflexively with certain of the premises underlying it. Nielsen rightly challenges taken-forgranted assumptions about law, freedom, and harm, and, in so doing, provides an important and clear account of law's relationship to social power. However, the same critical consideration is not shown to the stranger, their social identity and location, or to their relationship to public and private. Nielsen describes public spaces as among the last remaining places for racist and sexist expression "without reprisal both because the target fears further violence and because the speaker and the target do not know one another" (5). In the absence of also considering how and whether stranger contact might undo social inequalities of gender and race, License to Harass converges with popular perceptions that the streets and strangers are dangerous for women and others like us.

One reason for this narrow perspective may be Nielsen's subjectivist methodology (4-5), a methodology deeply invested in the perspectives and outlooks of those interviewed, at least as regards their views on stranger harassment. Nielsen presents the opinions and experiences of her interviewees in ways that are respectful of the narratives and perspectives she has been told by them. However, the limitation of this approach is the lack of an independent authorial voice critically locating and exploring alternate understandings of stranger contact (although other aspects of the story, such as the value of legal regulation, do receive more analysis). Nielsen writes, "conscious and unconscious biases, including racism, that are inherent in targets' analysis of [public] interactions, are captured rather than controlled for" (45). This may be. But one effect is that it becomes sometimes hard to tell whether claims about strangers are simply those of interviewees or reflective 
of Nielsen's outlook as well. This matters because the book is not just an ethnographic account of street harassment but a discussion also of a problem with analytical, normative, and strategic implications.

Second, while street harassment is located within wider systems of gender and racial subordination, the limited account both of strangers and the interplay of public and private shoehorns counterstrategies into a very narrow terrain. Despite some brief discussion of social movement responses to street intimidation, for the most part the counterstrategies discussed concern individual responses to harassment encountered. As Nielsen states, "what do targets do to reject the imposition of these constructions [of race and gender hierarchy] when such incidents occur in public places?" (10). Nielsen's datadriven analysis centers individual, largely privatizing solutions-avoiding eye contact (59), refusing to address strangers (59), avoiding certain spaces (63), not using train stations late at night (62-63). Elsewhere, Nielsen acknowledges the limits of this strategy (155). In relation to one woman whose tales to her employer of sexist street harassment led to him offering to pay her parking costs, Nielsen describes her "ced[ing] control of public space. Although it improves her individual situation, this solution does nothing to affect the social problem" (155). Nielsen clearly recognizes the need for more collective, long-term strategies that do not improve one person's immediate situation at the expense of others forced to use common spaces now even further evacuated. However, her methodology means that strategies based on creating vibrant, richly interactive and stimulating public spaces, or that explore the potential of other socially inventive practices to "imprint" on street harassment "from a distance" remain unaddressed.

Finally, a more pluralistic or polycentric view of law might have assisted Nielsen in circumventing state law as the solution, in the face of interviewees' objections to regulation. Nielsen's focus in License to Harass is ordinary people's legal consciousness; yet, perhaps for this reason (as well as her focus on First Amendment rights), law's appearance is very much law writ large. Despite the reference to McCann and March's $(1996,210)$ discussion of law as "modes of knowledge . . . and processes that citizens routinely deploy in practical activity" (Nielsen 2004, 9), License to Harass tends to adopt a clear divide between the legal and illegal (203), and between law and nonlegal social norms and rules. Although Nielsen acknowledges the mutual constitutivity of the latter (175), they are far from being analogous. As a consequence, once legal regulation is rejected, at least by many interviewees, nothing law-like remains to be put in its place. Nielsen ends her book with the remark, "It may very well be that the policy choice we have made in favor of free speech in America is the correct one" (180). But if this is the case, what other strategies exist effectively to challenge or outlaw sexist and racist comments? Self-help measures, as Nielsen suggests, are limited, particularly given targets' fear of further attack. The conclusion proposes awareness-raising of the problems associated with "offensive public speech." 
But not only do such attitudinal strategies sit uneasily alongside the systemic character of subordination that Nielsen has described, they also, Nielsen suggests, often follow legal change (178).

In the discussion that follows, I seek to contextualize and complement Nielsen's study by drawing on a different set of literatures and by posing two contrasting empirical examples that demonstrate how stranger contact can take a more positive form, to challenge rather than reproduce social hierarchy. I have chosen these examples to illustrate my point because they are spaces that I have studied and therefore feel I can say something about. Many other examples of counternormative stranger contact could have been used. Yet, my aim is not to suggest that Nielsen should have discussed such spaces - that would have been a very different book. Rather, I want to use the opportunity this essay offers to establish a dialogue between diverse stranger spaces. Doing so will, I hope, allow me to reflect more critically on the premise of civil inattention, on the emotional stakes involved in hailing and (mis)recognizing unknown others, and on the relationship between stranger contact and relations of inequality.

\section{AGAINST CIVIL INATTENTION}

As a description of the normative framework governing stranger interactions in (post)twentieth-centry Northern cities, civil inattention needs complicating (see also Goffman 1963, 125-27). This has implications for License to Harass, which treats civil inattention as a governing premise, breach of which defines and constitutes street harassment's harm (at least in part). I want to start by mapping three challenges to civil inattention to demonstrate the extent to which everyday stranger interactions derogate from its assumptions. However, these forms of interaction are not the primary focus of this essay, which is concerned with spaces of stranger contact established to deliberately offer alternative normative frameworks.

\section{A. Everyday Exceptions}

"Civil inattention" can first be seen as a culturally specific presentation based on middle-class Anglo-Protestant values (Sennett 1990) that inadequately describes interactions among nondominant social constituencies.

Various scholars have explored other normative patterns for street and stranger contact based on casual interactions, unsolicited inquiries, and loud informal hailing. These include Zukin's (1995, ch. 6) work on acquaintance and stranger interactions in the Jewish neighborhood shopping streets of her childhood, Daly's (1998) discussion of homeless stranger contact (see also Groth 1994), Anderson's (1990) work on young black men's interactions 
on the streets of New York, and Bell and Binnie's (1998) discussion of lesbian and gay urban exchanges (see also Podmore 2001).11

Alongside such socially structured, often spatially segmented, forms of normative pluralism, routine contact occurs across and against locally prevalent norms of interpersonal inattention. Gardner $(1995,64)$ explores, in some detail, how requests for mundane "public aid," such as the time and directions, what Williamson (2002) describes as "stranger civilities," are performed in all sorts of city spaces as Goffman has also noted;12 requests carrying with them the expectation that the query will be courteously addressed. Other routine conversations occur in specific quotidian spaces-outdoor waiting being a common example-whether for children outside a school or at a bus or coach station (indoor waiting in airports or doctors surgeries seems to generate less verbal or overt visual contact). Conversations with strangers during long train or plane journeys are also commonplace; these conversations hold the potential for contact that goes beneath the emotional skin, undoing the garment of privacy worn with people unknown. Simmel $(1971,145)$ writes that the most surprising revelations and confidences, on matters carefully hidden from those close to the speaker, often emerge in conversation with strangers.

Travel, arguably, functions as a liminal space, not because it lies at the edge of everyday spaces, but rather because the process of travel transgresses spatial fixities-offering a disembedded kind of place. Here, contact configurations are unsettled-intimacies can be exchanged, but names often may not be, underscoring the one-shot nature of the meeting (Goffman 1963, 139). Other liminal moments occur in unexpected temporal ruptures-commonly transportation breakdown and delay, as well as more serious crises. Usually brief, transient, one-shot occasions, these moments of exception gel strangers into community, as the ties of a suddenly shared experience affectively privatize, if temporarily, the common space occupied (e.g., see Humphreys 1974, 12). These three cases of socially acceptable interaction do not negate the possibility of harassment or sexist/racist speech. Suddenly hearing offensive opinions from an adjacent person in a plane, in the midst of a pleasant personal conversation, is commonplace. While the expression of such opinions differs from Nielsen's account in that the statements are usually not intended to offend the listener, they may nevertheless do so on account of a misrecognized

11. Other work highlights the temporal specificity of "civil inattention"-demonstrating, for instance, the very different norms that prevail on nighttime city streets (e.g., see Cresswell 1998). 12. Goffman (1963, 125-27) identifies five primary situations in which engagements among unacquainted people in middle-class, mid-century American society are permissiblewhere people are "available" to those not previously met. They are (1) through employment as a salesperson or receptionist; (2) particular statuses, such as very young or old, who are thus seen as "open"; (3) when out of one's own serious role, for instance, visibly drunk, in costume, engaged in lighthearted sport, or after momentarily tripping or falling; (4) the brief provision of help, opening a door, or picking up something accidentally dropped; and (5) as solicitous inquiries to smoke or in apologies for unintended bumping. 
social identity or politics. Indeed, this kind of situation, while unlikely to threaten violence, may prove far harder to extricate oneself from, thanks to the social conventions governing friendly chitchat, than where hostile intentions are visible from the start.

The role played by different spatialities and cultures in shaping communication norms is little discussed in License to Harass, which, for the most part, assumes a common norm of civil inattention. However, given the spectrum of temporal and socioeconomic spaces Nielsen's subjects utilized, it is likely that some experienced and responded to offense and the discursive production of subordination in contexts governed by other norms. This raises interesting and important questions about what then constitutes degrading speech, and, importantly, degrading nonspeech in contexts where gendered or racialized forms of subordination come not from what is said but from what is not said-where stranger speech rather than silence is the norm.

\section{B. Alternative Modes of Stranger Interaction}

In the discussion that follows, I explore two instances of counternormative stranger interactions in spaces oriented toward attention rather than its converse. These interactions, and the normative structures they condense (see Cooper 2004), go beyond the normative urban pluralism just identified. They are not simply concerned with coexisting spaces, peoples, or temporalities attuned to different cultural and social norms, but spaces and practices directly and deliberately forged to counter (and as counters to) prevailing norms and relations of power. Small-scale and frequently marginalized, with stranger exchanges at their heart, these spaces provide an important counterpoint to those Nielsen discusses.

Various writers have explored how working-class and poor people use their bodies, signs, and voices, within public spaces, to resist the processes and practices of power (e.g., Staeheli and Thompson 1997). From graffiti to abuse, transgressing reasserts the agency and subjectivity of the subjugated, contests prevailing meanings, and redirects scopic attention (see also Berman 1983, 153; Cover 2002). While some critics argue that public space and, even more, the public sphere is appropriated by those with private power (see Mitchell 1995, 116-17), streets seem to offer territory for those with little else, even if the power ceded by such territory is presently being eroded in global Northern cities through planning and urban policy development (Mitchell 1995).

Although class is not the focus of Nielsen's analysis, she recognizes its power in her discussion of the constitutionality of prohibitions on begging and in her recognition that street harassment is sometimes deployed to trouble or disrupt class and status hierarchies (Nielsen 2004, 35). However, with 
the exception of begging, Nielsen's sympathies appear to lie largely with those on the receiving end of harassment. While her discussion provides a salutary reminder to those writers who celebrate public space in ways that ignore its sometimes exclusionary and oppressive character, particularly for women, I would have liked to see License to Harass engage more fully with the way stranger contact can be deployed to unsettle the confident use of public space by powerful others. To illustrate this kind of use, I want to introduce Speakers' Corner, in London's Hyde Park. Speakers' Corner complements Nielsen's discussion in interesting ways. It reveals how speech between strangers-speech often in its form and content not that different from the harassing speech Nielsen discusses_-can, thanks in part to its location, have significantly different effects. That is, it can be not only unthreatening but also enriching, unsettling relations of social hierarchy through different norms of appropriate stranger exchange.

\section{Public Speech from the Margins}

Speakers' Corner, located in the northeast corner of Hyde Park in Central London, has provided an outdoor space within which strangers can gather to engage in oratory, political debate, and religious proselytism for over a century (Coleman 1997; Roberts 2000, 2001). Historically, its origins lie in the struggle of poor and working-class people to have spaces in which to protest and debate, and it continues today to provide a counterpublic space for those without access to mainstream media because of their political, religious, or social marginality (generally Fraser 1990). Thus, at the turn of the twenty-first century, the space is mainly used by Islamic and evangelical Christian groupings, a few Marxist factions, anti-imperialist orators and a handful of barely intelligible iconoclasts.

Elsewhere, I have explored the relations of strangeness and familiarity present at the Corner (Cooper 2006). While regulars form a loose kind of community, most present are occasional participants. It is in the combination of multishot and one-time players that the Corner comes to generate a space rich in the different dimensions of strangerness already discussed. Alongside strangerness in the form of normative difference and uncertain legibility (where participants struggle to make sense of other participants they encounter), the Corner is a space of social, economic, and global geographic diversity. At the turn of the twenty-first century, it is used by London's poor, alongside middle-class visitors and tourists, the mentally fragile and well, religious believers and secularists, right-wing and left-wing, young, middle-aged and old. Combined, these differences provide obstacles, but also, and crucially, motivations for contact. Regulars do not attend weekly to talk to each other but to engage - with varying degrees of intensity and seriousness of purposepassersby. In contrast to Nielsen's study, at Speakers' Corner, it is strangerness 
that provides the currency for rewarding and stimulating interactions as people talk informally in small, intensively engaged clusters, watch the spectacle of otherness before them, or mill in varying sized crowds around soap-box speakers.

Yet, while speech is the medium of stranger interaction, it is far from sanitized. In the course of arguments, oratory, and heckling, female audience members and speakers (of which there are very few) are sexualized and insulted; racist, anti-Semitic and nationalistic remarks are commonplace; and homophobia is pervasive (Mcllvenny 1996a, 1996b). While some comments are intended to wound, many appear driven by the desire to make contact and to induce a response from strangers and acquaintances present. Unlike the risk Nielsen's informants identified in speaking back to harassers, at the Corner talking back abounds. Regulars, in particular, but one-timers too, talk back, securing and reproducing speech's authority as the means of engaging with talk that offends. While embarrassment may be felt or risked, in other respects the Corner is a physically safe space where contact can be reciprocated. In the process, misrecognition is claimed and politically challenged, as audiences contest the terms on which they are hailed-claiming the speaker has either mistaken what they are (an error of location) or has mistaken what what they are is (an error of category).

It is the permission to speak back in a context of incredible social diversity that gives the Corner much of its richness. While the harassment Nielsen describes is far from amusing or pleasant, here insults can be safely and enjoyably exchanged, and often are deployed for their carnivalesque quality (Cooper 2006; see generally Bakhtin 1968). Yet, what the Corner contributes to thinking about stranger contact goes beyond the warping of insults into fun; equally important is its demonstration of how stranger contact can articulate oppositional norms and, in the process, unsettle social hierarchies. I leave open here the question of the wider impact of such unsettling-the extent and ways in which it spreads beyond the Corner's spaces, times, and participants. However, while License to Harass implicitly suggests that civil inattention is the remedy to the street's reproduction of social hierarchy, Speakers' Corner suggests a very different answer.

Speakers' Corner does not challenge all forms of social inequality. While it allows anyone to speak back, its structure and ethos do little to challenge the speech-based reproduction of gender and sexual orientation norms (Mcllvenny 1996a, 1996b). However, the stranger exchanges it supports do challenge norms and hierarchies associated with English class. 13 In contrast

13. The Corner does not only unsettle class and social status through a deliberate refusal to conform to its discursive conventions; its transgressive character lies also in its practical withholding of status based on people's external position within occupational or social hierarchies, in the marginalization of professional knowledge and expertise, and in the content

of what is said as direct verbal exchanges attack class and other forms of privilege (Coleman 1997). 
to a national, middle-class etiquette, with its strong norms of appropriate stranger conduct in public, the Corner is a place in which you can start a conversation with anyone (or no one), talk intensely about politics, disagree strongly, ignore conventions of privacy by invading personal conversations, and express strong emotion to and in proximity of unknown others (Cooper 2006). Against middle-class conventions of rational, polite, nonintrusive conversation, Corner references to race, gender, class, sexuality, and nationality are invariably articulated to the sexual, bawdy, and flesh. Paralleling, but also reconfiguring through function and context, the crude sex-talk Nielsen discusses, participants at the Corner make and rebut arguments through derisory reference to opponents' background, sexual and digestive needs, bodily fluids, and genitalia. In this way, exterior social codings of class, sexuality, gender, and ethnicity are tied to the body turned inside out, as what has been most hidden becomes the target for humor and attack (Mcllvenny 1996a, 1996b).

Through pitting a deliberately proletarian and folk-based set of norms against middle-class convention, the Corner also functions as a sanctuary against normality. Against prevailing norms that cause people to distance themselves, anxiously, from those behaving oddly (Lofland 1973, 155), at the Corner "odd" behavior abounds. Many people with mental health problems are described as regular Corner users (Cooper 2006); yet, the space is also one in which the sane/insane divide does not easily hold. There are some parallels here with Nielsen's discussion of begging. License to Harass challenges an easy divide between normality and abnormality, arguing that public spaces are used by a variety of people in different ways. However, because Nielsen's study is largely from the perspective of the recipient or spectator, the panhandler or harasser becomes at best an avoidable nuisance, if occasionally a colorful part of the local scene. They remain, however, the stranger. What Speakers' Corner does is reveal the transgressive effect of reversal. Visitors passing through may declare that Corner participants are mad, weird, or strange, even as they enjoy a strangeness that can be easily left without it, in turn, leaving much of a mark upon them (see also Bauman $1995,10)$. At the same time, one-timer perceptions of who constitutes the stranger are challenged and undermined by Corner norms and ethos and by the fact that it is the "strange" participant who is most likely to be a regular and to belong. From this perspective, it is the awkward one-timer, who ignores local customs and refuses to play along, who constitutes the outsider (see also Harman 1988; Kusow 2004).

In many respects, the Corner, as a public space, epitomizes fantasies of the cosmopolitan street. This is not the street of License to Harass, which people, in the main, seek to pass along quickly on their way to some place else. Rather, it is a space where people stop or pause, are stimulated, observe, and-importantly_engage (see also Crouch 1998). Yet, the Corner has proven a difficult space to copy; attempts by public authorities in North 
America and elsewhere to deliberately manufacture open deliberative spaces have often proven unsuccessful. For the most part, counternormative stranger spaces have worked better as semipublic venues: bounded places, where entry is deliberate and where gatekeeping, threshold, or other entry conditions exist (see Humphreys 1974; Tattelman 1997).14

I want to explore these semipublic spaces, through means of an example, to complicate a model that associates stranger interactions with public open spaces and which juxtaposes against them private intimate spaces. License to Harass does not explicitly draw this distinction; however, given its focus on street harassment, the elision of stranger and public raises the question of whether the key concern is stranger contact or public contact. My reading of the book suggests that the harassment at its center concerns inappropriate contact by strangers regardless of where it occurs. What I therefore want to turn to consider is how "inappropriate" stranger contact, in a semipublic space, can be experienced positively-more precisely, how sexual interactions between unknown people can challenge rather than reinforce gender-based subordination. In so doing, I take up Nielsen's claim that for some people comments from strangers can be experienced as an acceptable way of displaying sexual interest (e.g., Nielsen 2004, 44). However, I reorient it. Thus, instead of focusing on sexualized street comments by men to unknown women, I want to take as example an enclosed space in which same-sex stranger sex occurs between women.

\section{Stranger Sex}

Men's bathhouses in the global North are culturally familiar as spaces in which men interact in sexually casual ways with unknown or little known others. Women's bathhouses are less known and less common. The one discussed here, Canada's first, has run since 1998 once or twice a year in Toronto in spaces largely reserved on other nights for men.15 Toronto Women's Bathhouse (TWB), with the colorful name, Pussy Palace, seeks to create a conducive, playful environment within which women, transmen, and transwomen can explore and enjoy their sexuality (Nash and Bain forthcoming) in ways not traditionally available, and in ways at odds with the asymmetrical gender performance discussed in License to Harass.

14. In making this claim, I take account of Jeyasingham's $(2002,81)$ and others' argument that transgressive sexual practices may be drawn to public spaces without thresholds on the grounds that commitment can there be performed quickly, equivocally (and therefore more safely), and because contesting the hetero-normativity of the space may be experienced as erotic. My focus however is a space that explicitly seeks to establish alternative norms and practices; for such spaces, thresholds can be facilitative in identifying and protecting already "committed" participants.

15. This discussion also draws on interviews with participants conducted in 2005-06. 
In considering how being in public appears when read not through street harassment, but through the counternormative space of the TWB,16 I return to the four themes discussed earlier, of the stranger, publicity/privacy, (mis)recognition and effects. My aim is to see how they configure differently in a space dedicated to casual sex between often unknown women. In the conclusion, I return to the question of how such spaces intersect the less celebratory terrain discussed by Nielsen.

The bathhouse stranger parallels Nielsen's stranger in several respects. Both concern people not previously encountered (although the threshold of what constitutes a prior encounter rendering someone known may be different). Likewise, both street harassment and bathhouse eros concern unknown others who are socially different, although here again the substance of the difference is somewhat different. While bathhouse sex may involve, as street harassment does, differences of class, ethnicity, and sexual orientation, as well as of gender, it is gender as a stylized performance of the self, rather than as a "real" social category, that functions as the primary axis of eroticised difference.17 However, it is in the response to strangerness between the two spaces that we can see the fundamental distinction. While Nielsen's stranger is read negatively as a source of risk and danger, at the bathhouse, stranger, strangeness, and strangerness are eroticized. This does not mean there is no risk. Women I interviewed talked about the need for care when engaging sexually with unknown women. However, as with Speakers' Corner, it is the unknownness of the unknown (and sometimes of the known too) that provides the primary impetus for engagement. 18 As one woman described,

16. The claim that TWB constitutes a counternormative space has been challenged on several counts. Nash and Bain (forthcoming) suggest its antipathy to lesbian feminism is tied to its general emphasis on hetero-gender desires and relationships, in which gender identities and cross-gender (although not cross-sexual) erotic pleasure is affirmed. TWB also articulates mainstream liberal norms of consent, autonomy, agreement, and reciprocity. Women are treated as self-realizing agents, who know what they want and are able to pursue their interests safely through making their wishes known. Within this framework, harm is the space beyond consent and participants are responsible for ensuring their consent (or dissent) is an informed one and effectively communicated (see "Pussy Palace Rules"). Yet, while TWB articulates many of the same liberal norms to those expressed in Nielsen's study, its suturing of these norms to women's same-sex sexual agency and erotic publicity moves it beyond the contours of the mainstream. 17. Gender works at the bathhouse in several ways. First, the bathhouse is open to all gender variants with the exception of "men born men," and some sexual interactions involve people occupying different gender categories (e.g., female with trans). Other sexual interactions involve women with different gender identities even as they continue to identify as female or as women. This includes butch-fem distinctions, as well as distinctions that cannot be read along a lesbian masculine-feminine spectrum. What the bathhouse, however, highlights, in ways that complicate Nielsen's discussion, is the capacity of gender to be stretched and reshaped by individual actors in ways that remain subject to social and relational processes but are not solely produced by them. 18. Not all forms of unknownness, however, are seen as erotically attractive. While the unreadable participant at Speakers' Corner may contribute to their entertainment value, and while the normative outsider on the street may be given some license for not intending to insult, at the bathhouse women often avoid engaging sexually with unknown women whom they cannot read or with whom effective communication seems difficult. 
"I go there with a few friends and then ... after we've all gotten comfortable ... then it's break off, break off, break off . . . everyone's trying to get their groove on ... and they're not trying to do so with friends ... but with somebody new." 19

In reading stranger interactions through the bathhouse, the complicated relationship of public to private comes also to the fore (see also Humphreys 1974; Jeyasingham 2002; Leap 1999). I considered earlier how the public spaces and relations of street harassment are imbued with—not necessarily reciprocal or consensual-privatized connections and norms, where street harassment underscores the inappropriate nature of intimate remarks to strangers in shared spaces. My discussion of Speakers' Corner suggested personal remarks between strangers can work differently-to enliven the playful character of an agonistic public space. In the bathhouse context, the interplay of public and private works similarly to enhance the sexual nature and possibilities of the space. So, women meet at a venue that, while open to the public, depends on a committed decision to cross the threshold. Sexual interactions or intimacies happen between people who may well relate as public members, sharing little personal information in the course of engaging in erotic transactions. And sexual encounters take place in a wide variety of more or less private bathhouse spaces, offering varying degrees of physical seclusion, with varying levels of observation or participation by interested others.

In this way, the bathhouse, consensually and collectively, splices public and private together in ways intended to enhance the erotic character of the exchange. Yet, the ability of the space to provide safe and positive erotic experiences depends also on the extent and ways in which recognition occurs. In a women's bathhouse, where norms are new and unfamiliar, and etiquette unrehearsed, misrecognizing another's intentions, permissions, and preferences is easy (see generally Goffman 1972), despite the work performed by the organizers in creating, and promoting, bathhouse conventions of proper conduct.20 TWB suggests the possibility for errors of intent and expectation in ways that parallel other public, sexualized interactions, including those Nielsen discusses. In other respects, misrecognition has a very different character in the consensual sexual space of the bathhouse compared to the involuntary terrain of Nielsen's street insult. Street harassment works through the investment and inextricable relationship between subjects and their social identities - that one feels the insult when one's gender or ethnic identification is assaulted. Even when the harasser gets it "wrong," anxiety arising from

19. Interview on file with author.

20. See "Pussy Palace Rules." In the TWB's first few years, misrecognition also occasionally arose in relation to the complexities and legibilities of gender, among both participants and organizers, given the bathhouse policy that men born men were not welcome but all other gender variants were (see Nash and Bain forthcoming). 
how one is read or the hostility with which one is read is unlikely significantly to reduce the level of discomfort experienced. In the bathhouse, by contrast, social identity, or at least some social identities, are less rigidly experienced. Participants play with who they are and who the others that they play with might be. Although sometimes fraught, mishailing, in this way-or rehailingboth self and others has the potential to create new sexual opportunities in a space where women are seeking to develop and realize a reconstituted, reimagined sexual potential.

Reading being in public through street harassment underscores the banal, everyday ways in which women's subordination is reproduced. Against this reading, the lens provided by a women's bathhouse emphasizes pleasure, inventiveness, new stranger relations and the challenge of undoing women's sexual oppression. Nash and Bain (forthcoming) have suggested that the TWB adopts a working-class, queer sexual aesthetic for which gay male sexual practices provide the standard. While interviews I conducted show the influence, in practice, of feminized modes of connection and interaction (including, for many, the need to engage in some familiarizing chat before sex), a major aspiration of the bathhouse organizers, inspired by gay male culture, was women's acquisition of a more permissive and adventurous approach to their sexuality - at bathhouse events and more generally. This liberatory focus, with its clear investment in a repressive hypothesis of female sexuality (that it is women's shame and internalized social obligation to say no that needs overcoming), does not mean a women's bathhouse is a better lens to understanding being in public. In many respects, the lens offered by the bathhouse is a marginal and utopian one, barely relevant to most women's lives. At the same time, set alongside street harassment, the bathhouse example reminds us that public stranger exchanges are not invariably unpleasant and oppressive. In different ways, they can also contribute to the stimulating and enriching quality of civil society and to contesting relations of subordination.

\section{CONCLUSION: CONNECTING DIFFERENT SPACES}

Speakers' Corner and the Toronto Women's Bathhouse offer two very different examples of being in public. But what relationship do they have to street insults? If it is unremarkable that invented spaces of consensual interaction, oriented towards pleasure, operate differently to spaces of hostile, unreciprocated conduct, what value is there in discussing places of public oratory and sexual exchange alongside public harassment? In this review essay my reason for doing so has been fourfold. First, I wanted to present these other spaces of stranger interaction as a counterpoint or balance. Laura Beth Nielsen's study is one part of the story of how unknown people interact with each other in Northern urban environments. However, given the 
pervasiveness of cultural discourses currently that constitute the stranger as dangerous, and that warn against interacting with persons unknown (see also Wells 2005), it seems to me important to underscore the presence (and viability) of very different kinds of social interactions, where unknown others are experienced as stimulating, pleasurable, and even, given the promised one-shot nature of the encounter, as peculiarly safe.

Second, the questions and issues License to Harass raises-regarding the power of social practices, the different ways participants and bystanders think about the practices they encounter, the gap between perception and conduct, and the relationship of participants to "external" legal norms and instrumentsprovides a productive springboard into thinking about other normative practices. Reading Speakers' Corner and the Toronto Women's Bathhouse through the questions raised by License to Harass highlights how norms of public and private conduct can be reconfigured so intimate speech or sexual conduct, between strangers, is experienced as exciting rather than stressful. Such a reading also highlights the potential for recognition to be playfully contested or sidestepped, for misrecognition to occur through the repudiation of the recipient, and for exchanges between strangers to unsettle, fail to cohere with, or challenge conventional performances of gender, sexuality, class, and race.

Yet, while License to Harass can offer a springboard into analyzing other stranger exchanges, does using it in this way take us any further than simply recognizing that stranger practices are varied? To what extent can we-should we- use the claims made about Speakers' Corner and the Toronto Women's Bathhouse to reread or "queer" street harassment-to reconstitute it, interpretively and even more practically, as edgy, dynamic, or disruptive, productive of alternative forms of interpellation, publicity, and identity disavowal? Pursuing such an analysis has its attractions, particularly in its seeming capacity to turn (or reread) a practice denounced as offensive, injurious, and consolidating of gender and racial inequalities into one that is transgressive of the status quo, liberatory, or empowering for subordinated constituencies. However, Nielsen's careful account, with its almost ergonomic attention to, and wrapping around of, interviewee perceptions, places doubt on the value and, certainly, on the resonance of an agonistic engagement with harassment. I read License to Harass to say that in treating offensive public speech as a game or tournament between formally equal contenders, the power of abuse and harassment is not productively diminished but unproductively trivialized.

Speakers' Corner and the Toronto Women's Bathhouse are clearly not analogous spaces to the ones Nielsen discusses. Yet, examining them in the context of street harassment raises questions and issues that, I think, can augment Nielsen's analysis. In particular, these counterspaces invite us to relocate street harassment within a wider perspective of being in public. By challenging prevailing assumptions-principally, that stranger contact should be superficial, nonintimate and nonintense-my two counterexamples push 
us to think hard about what foundations of normative stranger contact underpin critiques of harassment. Identifying harassment as problematic does not depend upon the premise of "civil inattention," however, what constitutes harassment-or what progressive critics might wish to define as harmful stranger or street conduct-may look quite different if norms other than those of civil inattention are read as foundational.

My final reason for using License to Harass as a springboard into thinking about other counternormative stranger exchanges responds to Nielsen's underlying concern that street harassment contributes to sexual and racial subordination and that the law can do little to stop it. If law's power is limited, or if it is liable to cause as much harm as good, what other mechanisms are available to contest the norms that permit gender and racial harassment, rendering it sensical to those who participate in its practice? This is a difficult question, and one open to many different responses. One trajectory of thought might focus on the material conditions underpinning socioeconomic, gender and racial inequalities that are then given voice through street harassment, albeit in complex ways. A complementary approach, based on my discussion in this essay, addresses the interplay of different normativities.

Legal pluralism, particularly critical legal pluralism, may be useful here. Autopoietic versions of legal pluralism suggest that normative orders are distinct communicative systems-influencing each other through the "external noise" or perturbations that cause discourses to evolve and adapt, if on their own terms (Teubner 1992, 1453; see also Moore 1978). Critical legal pluralism, by contrast, focuses on the hybrid and interconnected character of normative orders. Macdonald $(1998,77)$ writes, "Different legal regimes are in constant interaction, mutually influencing the emergence of each other's rules, processes and institutions." 21 Practices may be produced out of and display an array of diverse and hybrid norms; however, my argument in this essay depends on the presumption, shared by Nielsen, that certain norms or clusters of norms dominate particular spatialized practices (see also Herbert 1996). If this is the case, how then do differently organized normative spaces interconnect? More precisely, how do the norms governing Speakers' Corner and the Toronto Women's Bathhouse intersect those expressed in street harassment encounters?

This essay started from the premise that there is no necessary convergence. Normative pluralism in relation to stranger exchanges can comfortably coexist-so we can fear street harassment from strangers, at the same time

21. This normative pluralism also takes shape at the level of individual subjectivity (Kleinhans and Macdonald 1997; Manderson 1995-96, 2000; see also Galanter 1981). So, as License to Harass explores, individuals may produce free speech arguments in certain contexts, but not in others; feel the law should intervene when harassment crosses this line, but not that line; or want informal police management of a situation, while simultaneously expressing apprehension at the inappropriate or excessive use of policing discretion (see also Nielsen 106-07). 
as we may talk intimately to them on a plane or train journey, argue with them at Speakers' Corner, provide help when it seems needed or is asked for, and engage sexually with people we never before met.22 The capacity of contrasting norms to coexist is clearly beneficial for minority social practices, which do not always have to function as antinormative but can rely for legitimacy and sustenance on the presence of local values and rules that declare their rightness. However, this does not take us far forward in thinking about how the presence of alternative normative spaces can "impress upon" the norms governing more mainstream practices, such as street harassment. Indeed, it may suggest the reverse is that case- that norms are produced by the material and cultural conditions of particular contexts and relations while remaining relatively inured from outside influence.

Critical legal pluralism rejects this kind of bounded normativity, and it seems intuitively right that multiplying spaces of counternormative engagementin which people interact with unknown others in radically different wayswill affect the civil inattention, recipient passivity, and social hierarchy frequently performed through street harassment. Concepts such as habitus, pathways, and governing or imprinting from a distance hold some promise in thinking through how practices interconnect and impact upon each other, while more autopoietic readings of legal pluralism instructively remind us that "external" norms can be incorporated in nonnormative ways (for instance, as a penalty, threat or resource) (e.g., see Teubner 1992, 1454). At the same time, philosophical challenges to linear models of causation and geometric models of space complicate how we understand the relationship between divergent normative practices. We cannot simply follow a chain of linkages through adjacent time and space to see how one set of practices shapes another.

Laura Beth Nielsen's book is a marker that what we want and feel to be true may not prove to be so. In the case of street harassment, that means recognizing, on the one hand, that law is not necessarily an effective regulatory structure, and that, on the other, people do not necessarily perform the challenges to social subordination they avow. However, Nielsen also, importantly, does not draw from this that the solution is acquiescence but rather the need to search for other possible responses. It is in the spirit of this search that I have used street harassment as a springboard into exploring some instances of counternormative talk and sex as alternatively constituted, if complexly constitutive, public stranger spaces.

22. While critical legal pluralism suggests we can sustain all these relations simultaneously, it is also evident that organizing principles of class, gender, sexuality, age, and ethnicity, amongst other things, structure who does what with whom (and where). 


\section{REFERENCES}

Ahmed, Sara 2000. Strange Encounters: Embodied Others in Post-Coloniality. London: Routledge.

Anderson, Elijah. 1990. Streetwise: Race, Class and Change in an Urban Community. Chicago: University of Chicago Press.

Bakhtin, Mikhail. 1968. Rabelais and His World. Cambridge, MA: MIT Press.

Bauman, Zygmunt. 1988-89. Strangers: The Social Construction of Universality and Particularity. Telos 78:7-42.

- 1995. Making and Unmaking of Strangers. Thesis Eleven 43:1-16.

Beck, U. 1998. Democracy without Enemies. Cambridge: Polity.

Bell, David, and Jon Binnie. 1998. Theatres of Cruelty, Rivers of Desire: The Erotics of the Street. In Images of the Street, ed. Nicholas Fyfe, 129-40. London: Routledge.

Berman, Marshall. 1983. All That Is Solid Melts into Air. London: Verso.

Boddy, Trevor. 1992. Underground and Overhead: Building the Analogous City. In Variations

on a Theme Park, ed. Michael Sorkin, 123-53. New York: Hill and Wang.

Butler, Judith. 1997. Excitable Speech London: Routledge.

Calavita, Kitty. 2001. Blue Jeans, Rape, and the "Deconstitutive" Power of Law. Law \&

Society Review 35:89-115.

Calhoun, Craig, ed. 1999. Introduction: Habermas and the Public Sphere. In Habermas and the Public Sphere. Cambridge, MA: MIT.

Chambers, Ian. 1990. Border Dialogues: Journeys in Postmodernity. London: Routledge.

Cohen, Jean. 1999. Personal Autonomy and the Law: Sexual Harassment and the

Dilemma of Regulating "Intimacy." Constellations 6:443-72.

Coleman, Stephen. 1997. Stilled Tongues: From Soapbox to Soundbite. London: Porcupine Press.

Cooper, Davina. 2004. Challenging Diversity: Rethinking Equality and the Value of Difference.

Cambridge: Cambridge University Press.

_. 2006. "Sometimes a Community and Sometimes a Battlefield": From the Comedic

Public Sphere to the Commons of Speakers' Corner. Society and Space 24:753-775.

Cover, Rob. 2002. Some Cunts: Graffiti, Globalisation, Injurious Speech and "Owning"

Signification. Social Semiotics 12:269-90.

Cowan, Gloria, and Cyndi Hodge. 1996. Judgments of Hate Speech: The Effects of Target

Group, Publicness, and Behavioral Responses of the Target. Journal of Applied Social

Psychology 26:355-74.

Crawford, Margaret. 1992. The World in a Shopping Mall. In Variations on a Theme Park, ed. Michael Sorkin, 3-30. New York: Hill and Wang.

Cresswell, Tim. 1998. Night Discourse: Producing/Consuming Meaning on the Street.

In Images of the Street, ed. Nicholas Fyfe, 268-79. London: Routledge.

Crouch, David. 1998. The Street in the Making of Popular Geographical Knowledge.

In Images of the Street, ed. Nicholas Fyfe, 160-75. London: Routledge.

Daly, Gerald. 1998. Homelessness and the Street: Observations from Britain, Canada and the United States. In Images of the Street, ed. Nicholas Fyfe, 111-28. London: Routledge. Day, Kristen. 2001. Constructing Masculinity and Women's Fear in Public Space in Irvine, California. Gender, Place and Culture 8:109-27.

Deleuze, G., and F. Guattari. 1986. Nomadology. New York: Semiotext(e).

Ewick, Patricia, and Susan Silbey. 1998. The Common Place of Law. Stories from Everyday

Life. Chicago: University of Chicago Press.

Franck, Karen. 1980. Friends and Strangers: The Social Experience of Living in Urban and Non-urban Settings. Journal of Social Issues. 36:52-71.

Fraser, Nancy. 1990. Rethinking the Public Sphere: A Contribution to the Critique of Actually Existing Democracy. Social Text 25-26:56-80.

Galanter, Marc. 1981. Justice in Many Rooms: Private Ordering, and Indigenous Law.

Journal of Legal Pluralism 19:1-47.

Gardner, Carol Brooks. 1995. Passing By: Gender and Public Harassment. Berkeley: University of California Press.

Goffman, Erving. 1963. Behavior in Public Place. New York: Free Press. 1969. The Presentation of Self in Everyday Life. Harmondsworth, Middlesex: Penguin.

- 1972. Interaction Ritual: Essays on Face-to-Face Behaviour. Harmondsworth, Middlesex: Penguin.

Goheen, Peter. 1998. Public Space and the Geography of the Modern City. Progress in

Human Geography 22:479-96.

Goss, Jon. 1996. Disquiet on the Waterfront: Reflections on Nostalgia and Utopia

in the Urban Archetypes of Festival Marketplaces. Urban Geography 17:221-

47.

Gotham, Kevin. 2002. Marketing Mardi Gras: Commodification, Spectacle and the Political

Economy of Tourism in New Orleans. Urban Studies. 39:1735-56. 
Groth, Paul. 1994. Third and Howard: Skid Row and the Limits of Architecture. In Streets: Critical Perspectives on Public Space, ed. Zeynep Celik, Diane Favro, and Richard Ingersoll, 23-34. Berkeley: University of California Press. Harman, Lesley. 1988. The Modern Stranger. Berlin: Mouton de Gruyter. Herbert, Steve. 1996. The Normative Ordering of Police Territoriality: Making and Marking Space with the Los Angeles Police Department. Annals of the Association of American Geographers 86:567-82.

Hershkovitz, Linda. 1993. Tiananmen Square and the Politics of Place. Political Geography 12:395-420.

Hill, Jane. 1998. Language, Race, and White Public Space. American Anthropologist 100:680-89.

Humphreys, Laud. 1974. Tearoom Trade. London: Duckworth \& Co.

Jackson, Peter. 1998. Domesticating the Street: The Contested Spaces of the High Street and the Mall. In Images of the Street, ed. Nicholas Fyfe, 176-91. London: Routledge. Jacobs, Jane. 1961. The Death and Life of Great American Cities. New York: Random House. Jankowiak, William, and C. Todd White. 1999. Carnival on the Clipboard: An Ethnological Study of New Orleans Mardi Gras. Ethnology 38:335-49. Jeyasingham, Dharman. 2002. "Ladies" and "Gentlemen": Location, Gender and the Dynamics of Public Sex. In In a Queer Place: Sexuality and Belonging in British and European Contexts, ed. Kate Chedgzoy, Emma Francis, and Murray Pratt, 73-88. Aldershot, Hampshire: Ashgate.

Kleinhans, Martha-Marie, and Roderick Macdonald. 1997. What Is a Critical Legal Pluralism? Canadian Journal of Law and Society 12:25-46.

Koskela, Hille. 1997. Bold Walk and Breakings: Women's Spatial Confidence Versus Fear of Violence. Gender, Place \& Culture 4:301-21.

Kusow, Abdi. 2004. Contesting Stigma: On Goffman's Assumptions of Normative Order.

Symbolic Interaction 27:179-97.

Leap, William, ed. 1999. Public Sex/Gay Space. New York: Columbia University

Press.

Lenton, Rhonda, et al. 1999. Sexual Harassment in Public Places: Experiences of Canadian Women. CRSA/RCSA 36:517-40.

Lofland, Lynn. 1973. A World of Strangers: Order and Action in Urban Public Space. Prospect Heights, IL: Waveland.

Macdonald, Roderick. 1998. Metaphors of Multiplicity: Civil Society, Regimes and Legal

Pluralism. Arizona Journal of International and Comparative Law 15:69-92.

MacKinnon, Catharine. 1996. Only Words. Cambridge, MA: Harvard University

Press.

Manderson, Desmond. 1995-96. Beyond the Provincial: Space, Aesthetics, And Modernist

Legal Theory. Melbourne University Law Review 20:1048-71.

2000. Songs without Music: Aesthetic Dimensions of Law and Justice. Berkeley: University of California Press.

Mason, Gail. 2005. Hate Crime and the Image of the Stranger. British Journal of Criminology 45:837-59.

Matsuda, Mari, et al. 1993. Words That Wound: Critical Race Theory, Assaultive Speech and the First Amendment. Boulder, CO: Westview Press.

Mcllvenny Paul. 1996a. Heckling in Hyde Park: Verbal Audience Participation in Popular Public Discourse. Language in Society 25:27-60.

—. 1996b. Popular Public Discourse at Speakers' Corner: Negotiating Cultural Identities in Interaction. Discourse \& Society 7:7-37.

McCann, Michael, and Tracey March. 1996. Law and Everyday Forms of Resistance: A Socio-Political Assessment. Studies in Law, Politics and Society 15:207-36.

Merry, Sally. 1986. Everyday Understandings of the Law in Working-Class America. American Ethnologist 13:253-70.

_. 1993. Mending Walls and Building Fences: Constructing the Private Neighborhood. Journal of Legal Pluralism 33:71-90.

Mitchell, Don. 1995. The End of Public Space? People's Park, Definitions of the Public, and Democracy. Annals of the Association of American Geographers 85:108-33.

Moore, Sally Falk. 1978. Law as Process. London: Routledge \& Kegan Paul.

Nash, Catherine, and Alison Bain. Forthcoming. "Reclaiming Raunch": Spatializing

Queer Identities at Toronto Women's Bathhouse Events. Journal of Social and Cultural

Geography.

Newman, Oscar 1973. Defensible Space. New York: Collier Books.

Nielsen, Laura Beth. 2004. License to Harass: Law, Hierarchy and Offensive Public Speech.

Princeton, NJ: Princeton University Press.

Park, Roberts. 1928. Human Migration and the Marginal Man. American Journal of Sociology

33:881-93.

Podmore, Julia. 2001. Lesbians in the Crowd: Gender, Sexuality and Visibility along 
Montréal's Boul. St-Laurent. Gender, Place and Culture 8:333-55.

Roberts, John. 2000. The Enigma of Free Speech: Speakers' Corner, the Geography of Governance and a Crisis of Rationality. Social \& Legal Studies 9:271-92.

—. 2001. Spatial Governance and Working Class Public Spheres: The Case of a Chartist Demonstration at Hyde Park. Journal of Historical Sociology 14:308-36.

Schwartzman, Lisa. 2002. Hate Speech, Illocution, and Social Context: A Critique of Judith Butler. Journal of Social Philosophy 33:421-41.

Sennett, Richard. 1990. The Conscience of the Eye: The Design and Social Life of Cities. New York: Alfred A. Knopf.

—. 1994. Flesh and Stone: The Body and the City in Western Civilization. London: Faber and Faber.

Silbey, Susan. 2005. After Legal Consciousness. Annual Review of Law and Social Science 1:323-68.

Simmel, G. 1971. On Individuality and Social Forms. Chicago: University of Chicago Press. Staeheli, Lynn, and Albert Thompson. 1997. Citizenship, Community, and Struggles for Public Space. Professional Geographer 49:28-38.

Tamanaha, Brian. 1993. The Folly of the "Social Scientific" Concept of Legal Pluralism. Journal of Law and Society 20:192-217.

2000. A Non-Essentialist Version of Legal Pluralism. Journal of Law and Society 27:296-321.

Tattelman, Ira. 1997. The Meaning at the Wall: Tracing the Gay Bathhouse. In Queers in Space: Communities/Public Places/Sites of Resistance, ed. Gordon Brent Ingram, Anne-Marie Bouthillette, and Yolanda Retter, 391-406. Seattle, WA: Bay

Press.

Teubner, Gunther. 1992. The Two Faces of Janus: Rethinking Legal Pluralism. Cardozo

Law Review 13:1443-62.

Tewksbury, Richard. 2002. Bathhouse Intercourse: Structural and Behavioral Aspects of Erotic Oasis. Deviant Behavior 23:75-112.

Wells, Karen. 2005. Strange Practices: Children's Discourses on Transgressive Unknowns in Urban Public Space. Childhood 12:495-506.

Williamson, K. M. 2002. Civility Proxies and Social Tolerance in American Marketplaces. Sociological Inquiry 72:486-99.

Wilson, J. Q. and G. Kelling. 1982. Broken Windows. The Atlantic Monthly 249:29-38

Wirth, Louis. 1938. Urbanism as a Way of Life. American Journal of Sociology 44:324.

Zukin, Sharon. 1995. The Cultures of Cities. Oxford: Blackwell. 